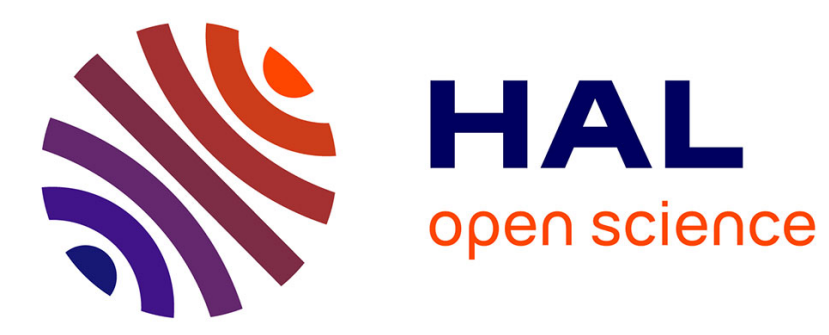

\title{
Differential Assembly of GPCR Signaling Complexes Determines Signaling Specificity
}

\author{
Pascal Maurice, Abla Benleulmi-Chaachoua, Ralf Jockers
}

\section{To cite this version:}

Pascal Maurice, Abla Benleulmi-Chaachoua, Ralf Jockers. Differential Assembly of GPCR Signaling Complexes Determines Signaling Specificity. Sub-cellular biochemistry, 2012, GPCR Signalling Complexes - Synthesis, Assembly, Trafficking and Specificity, 10.1007/978-94-007-4765-4_12 . hal02347754

\section{HAL Id: hal-02347754 \\ https://hal.science/hal-02347754}

Submitted on 13 Nov 2019

HAL is a multi-disciplinary open access archive for the deposit and dissemination of scientific research documents, whether they are published or not. The documents may come from teaching and research institutions in France or abroad, or from public or private research centers.
L'archive ouverte pluridisciplinaire HAL, est destinée au dépôt et à la diffusion de documents scientifiques de niveau recherche, publiés ou non, émanant des établissements d'enseignement et de recherche français ou étrangers, des laboratoires publics ou privés. 


\section{Metadata of the chapter that will be visualized online}

\begin{tabular}{|c|c|c|}
\hline Series Title & \multicolumn{2}{|l|}{ Subcellular Biochemistry } \\
\hline Chapter Title & \multicolumn{2}{|c|}{ Differential Assembly of GPCR Signaling Complexes Determines Signaling Specificity } \\
\hline \multicolumn{3}{|l|}{ Chapter SubTitle } \\
\hline Copyright Year & \multicolumn{2}{|l|}{2012} \\
\hline Copyright Holder & \multicolumn{2}{|c|}{ Springer Science + Business Media Dordrecht } \\
\hline \multirow[t]{14}{*}{ Corresponding Author } & Family Name & Jockers \\
\hline & Particle & \\
\hline & Given Name & Ralf \\
\hline & Suffix & \\
\hline & Division & \\
\hline & Organization & Inserm, U1016, Institut Cochin \\
\hline & Address & 22 rue Méchain, 75014, Paris, France \\
\hline & Division & \\
\hline & Organization & CNRS UMR 8104 \\
\hline & Address & Paris, France \\
\hline & Division & \\
\hline & Organization & University Paris Descartes \\
\hline & Address & Sorbonne Paris Cite, Paris, France \\
\hline & Email & ralf.jockers@inserm.fr \\
\hline \multirow[t]{14}{*}{ Author } & Family Name & Maurice \\
\hline & Particle & \\
\hline & Given Name & Pascal \\
\hline & Suffix & \\
\hline & Division & \\
\hline & Organization & Inserm, U1016, Institut Cochin \\
\hline & Address & 22 rue Méchain, 75014, Paris, France \\
\hline & Division & \\
\hline & Organization & CNRS UMR 8104 \\
\hline & Address & Paris, France \\
\hline & Division & \\
\hline & Organization & University Paris Descartes \\
\hline & Address & Sorbonne Paris Cite, Paris, France \\
\hline & Email & \\
\hline \multirow[t]{7}{*}{ Author } & Family Name & Benleulmi-Chaachoua \\
\hline & Particle & \\
\hline & Given Name & Abla \\
\hline & Suffix & \\
\hline & Division & \\
\hline & Organization & Inserm, U1016, Institut Cochin \\
\hline & Address & 22 rue Méchain, 75014, Paris, France \\
\hline
\end{tabular}


Author's Proof

\section{Division}

Organization

Address

Division

Organization

Address

Email

\section{CNRS UMR 8104}

Paris, France

University Paris Descartes

Sorbonne Paris Cite, Paris, France

Abstract

Recent proteomic and biochemical evidence indicates that cellular signaling is organized in protein modules. G protein-coupled receptors (GPCRs) are privileged entry points for extracellular signals that are transmitted through the plasma membrane into the cell. The adequate cellular response and signaling specificity is regulated by GPCR-associated protein modules. The composition of these modules is dynamic and might depend on receptor stimulation, the proteome of a given cellular context, the subcellular localization of receptor-associated modules, the formation of GPCR oligomers and the variation of expression levels of components of these modules under physiological, for example circadian rhythm, or pathological conditions. The current article will highlight the importance of GPCR-associated protein modules as a biochemical basis for signaling specificity.

Keywords (separated by Circadian rhythm - Compartmentalization - Complex assembly - Dimerization - Therapeutic '-') 


\section{Chapter 12 \\ Differential Assembly of GPCR Signaling Complexes Determines Signaling Specificity}

Pascal Maurice, Abla Benleulmi-Chaachoua, and Ralf Jockers

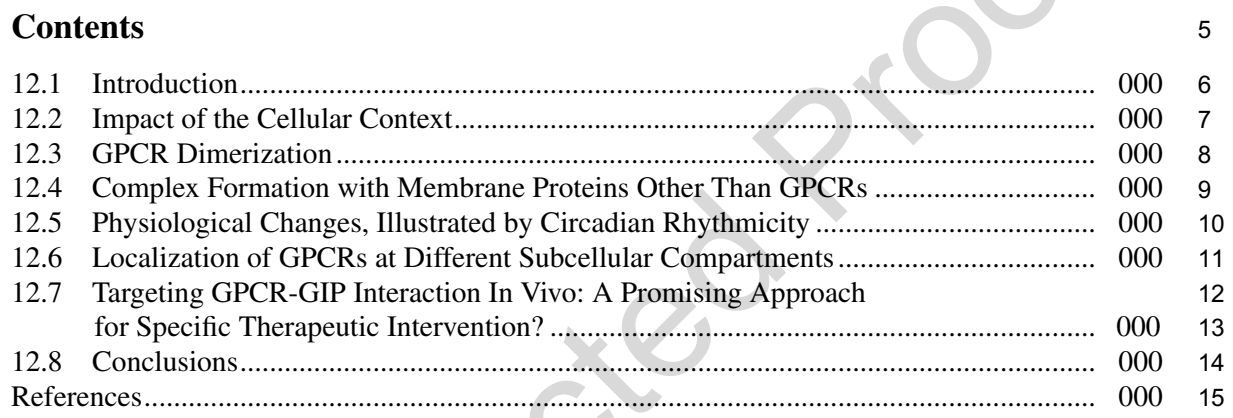

Abstract Recent proteomic and biochemical evidence indicates that cellular 16 signaling is organized in protein modules. G protein-coupled receptors (GPCRs) are 17 privileged entry points for extracellular signals that are transmitted through the 18 plasma membrane into the cell. The adequate cellular response and signaling 19 specificity is regulated by GPCR-associated protein modules. The composition of 20 these modules is dynamic and might depend on receptor stimulation, the proteome 21 of a given cellular context, the subcellular localization of receptor-associated mod- 22 ules, the formation of GPCR oligomers and the variation of expression levels of 23 components of these modules under physiological, for example circadian rhythm, 24 or pathological conditions. The current article will highlight the importance of 25 GPCR-associated protein modules as a biochemical basis for signaling specificity. $\quad 26$

P. Maurice $\bullet$ A. Benleulmi-Chaachoua $\bullet$ R. Jockers $(\bowtie)$

[AU2] CNRS UMR 8104, Paris, France

University Paris Descartes, Sorbonne Paris Cite, Paris, France

e-mail: ralf.jockers@inserm.fr 


\section{Author's Proof}

Keywords Circadian rhythm - Compartmentalization - Complex assembly • Dimerization - Therapeutic

\subsection{Introduction}

Membrane receptors are at the interface between the extra- and intra-cellular environment and are thus crucial for cellular communication. The superfamily of $\mathrm{G}$ protein-coupled receptors (GPCRs) constitutes the largest family of membrane receptors with approximately 800 members in humans (Vassilatis et al. 2003; Fredriksson and Schioth 2005). They are composed of seven transmembrane domains connected by short intra- and extra-cellular loops and respond to a large panel of signals: photons, ions, metabolites, amino acids, lipids, peptides and proteins. Despite this ligand diversity, the overall architecture and activation mechanism is believed to be highly conserved for these receptors. Many GPCRs are able to activate heterotrimeric $G$ proteins composed of $\alpha, \beta$ and $\gamma$ subunits. $G$ proteins are classified according to the activation of various effectors: $G_{\mathrm{i} / \mathrm{o}}$ and $\mathrm{G}_{\mathrm{s}}$ proteins are typically involved in the inhibition and stimulation of adenylyl cyclase, respectively; $\mathrm{G}_{\mathrm{q} / 11}$ proteins in the stimulation of phospholipase $\mathrm{C}$ and $\mathrm{G}_{12 / 13}$ proteins in the activation of small $\mathrm{G}$ proteins and cytoskeleton rearrangements. According to the type of $\mathrm{G}$ protein activated, GPCRs have been initially classified as $\mathrm{G}_{\mathrm{i} / \mathrm{o}}{ }^{-}, \mathrm{G}_{\mathrm{s}}{ }^{-}, \mathrm{G}_{\mathrm{q}^{\prime / 1}}{ }^{-}$or $\mathrm{G}_{12 / 13^{-}}$ coupled receptors. However, replication of these studies in different cell types and experimental conditions clearly show that most GPCRs do not couple to one single $\mathrm{G}$ protein but often to several of them. Activation of additional $\mathrm{G}$ protein-independent signaling events, i.e. B-arrestin-dependent pathways, are also increasingly described. The capacity of GPCRs to signal through multiple pathways together with the fact that signaling pathways are highly interconnected within networks raises the fundamental and still largely unsolved question of how signaling specificity is obtained upon stimulation of cells with a given ligand.

A simple way to generate signaling specificity is the expression of different receptor isoforms responding to the same ligand but triggering different signaling events (Fig. 12.1a). This strategy is widely used and applies to multiple neurotransmitters (serotonin, dopamine, glutamate, etc.). In other more limited circumstances, signaling specificity is generated by the expression of different natural ligands targeting the same receptor with different functional outcomes (Fig. 12.1c). Prominent examples are the $\beta 2$-adrenergic receptors ( $\beta 2 \mathrm{AR}$ ) that is activated by epinephrine and norepinephrine (Reiner et al. 2010) and the parathyroid hormone receptor (PTHR) that is activated by PTH and the PTH-related peptide (PTHrP) (Ferrandon et al. 2009). Epinephrine and norepinephrine induce different conformational changes within the receptor with different kinetics as monitored with a fluorescently tagged B2AR FRET sensor. These differences translate into different capacities to activate $\mathrm{G}_{\mathrm{s}}$ - and $\mathrm{B}$-arrestin-dependent signaling events. In the case of the PTHR, both natural ligands trigger different durations of the cAMP responses in which PTHrP-promoted actions are short-lived and restricted to the cell surface and 


\section{Author's Proof}

12 Differential Assembly of GPCR Signaling Complexes Determines Signaling...

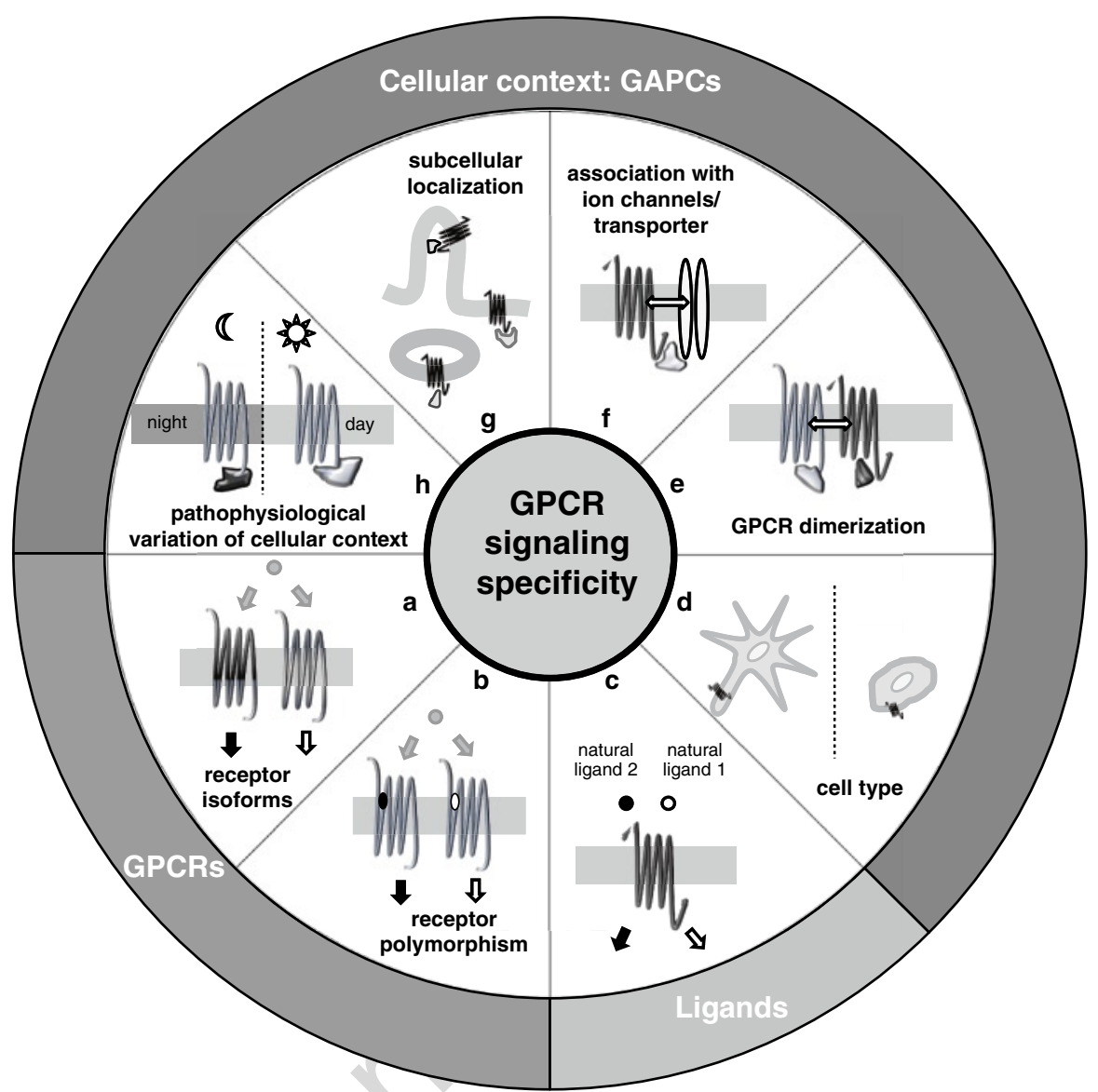

Fig. 12.1 Schematic illustration of different means to generate GPCR signaling specificity. (a) Stimulation of different receptor isoforms by the same ligand may result in the activation of different signaling pathways; (b) receptor polymorphisms may modify the functional properties of receptors; (c) different natural ligands may activate the same receptor differently; (d) receptor function may vary depending on the cellular context; (e) GPCR dimerization may modify receptor function and the recruitment of different GAPCs; (f) association of GPCRs with ion channels and neurotransmitter transporters may modify receptor function; (g) the subcellular localization of receptors may impact on receptor function; (h) the functional response of receptors may vary depending on physiological or pathological changes of receptor or GAPC expression. Changes in GAPC composition as a function of the circadian rhythm are illustrated

PTH-promoted actions are long-lived and dependent on receptor internalization. This idea can be also extended towards inverse agonists as illustrated by melanocortin MC3/MC4 receptors and their naturally occurring inverse agonists agouti and agouti-related protein (Agrp) that diminish the action of the melanocortin receptor agonist $\alpha$-melanocyte-stimulating hormone (Adan and Kas 2003). 


\section{Author's Proof}

The same strategy is increasingly applied by pharmaceutical industry to design synthetic ligands with biased signaling properties. The idea behind biased ligands is to develop drugs that activate only a subset of signaling pathways (ideally only those important for the therapeutic effect) thus significantly decreasing unwanted side effects of drugs due to the activation of therapeutically irrelevant pathways. The proofof-concept for such a strategy has been shown for the nicotinic acid receptor. Nicotinic acid is one of the most effective agents for both lowering triglycerides and raising HDL levels. However, the side effect of cutaneous flushing severely limits patient compliance. Recent evidence suggests that effects on lipid metabolism are mediated by $\mathrm{G}_{\mathrm{i} / \mathrm{o}}$ proteins and flushing by B-arrestin (Walters et al. 2009). Drugs with reduced flushing profiles are currently developed (Shen et al. 2010).

Furthermore, receptor polymorphisms might modify the signaling profile of the receptor and thus redirect the functional outcome (Fig. 12.1b). This aspect has to be considered in the context of personalized drug design.

Although the abovementioned cases participate in the generation of signaling specificity, they only apply to a subset of situations and leave the majority of cases unexplained. Indeed, the signaling outcome of the stimulation of a particular receptor might largely depend on the cellular context, the precise subcellular localization of receptors, their clustering and their interaction with signaling modules, whose composition might vary depending on different physiological or pathological conditions. The present article describes how signaling specificity can be generated under these different circumstances. We will focus our attention on the importance of GPCR-associated protein complexes (GAPCs) that might be either involved in the trafficking and subcellular localization of the receptor or directly in receptor signaling. Importantly, integration of receptors into different preformed signaling complexes might be a biochemical basis for the generation of signaling specificity.

\subsection{Impact of the Cellular Context}

Activation of specific signaling pathways and the functional outcome of receptor activation depend on the cellular context. This may include differences in the functional response depending on the differentiation state of cells, for example preadipocytes $v s$. adipocytes, or on the cell types (immune cells, epithelial cells, neurons, etc.). Differences may occur at the level of receptor expression, receptor localization, the expression pattern of effector systems and downstream signaling pathways as well as expression of components of GAPCs (Fig. 12.1d).

This is well illustrated by the regulator of $\mathrm{G}$ protein signaling (RGS) proteins. RGS proteins are GTPase-activating proteins that accelerate the GTPase activity of $\mathrm{G} \alpha$ subunits, thereby modulating $\mathrm{G}$ protein signaling (Sjogren 2011). In addition to their selectivity for certain $\mathrm{G} \alpha$ subtypes, one obvious source of specificity is the tissue- or cell-specific expression pattern of RGS. A good example is the distinct localization of the two splice variants of RGS9. RGS9, a member of the R7 family of RGS proteins, is expressed as two splice variants, RGS9-1 in the retina and the 


\section{Author's Proof}

longer form RGS9-2 primarily postsynaptic in dopamine receptor-rich brain regions, such as the striatum (Gold et al. 1997; Mancuso et al. 2010). In the retina, RGS9-1 is exclusively found in the outer segment of photoreceptor cells in which it regulates signaling through transducin $\alpha$ subunits in rods and cones (Cowan et al. 1998; He et al. 1998). This protein seems to be essential for normal visual perception as demonstrated by the RGS9 knockout mice and humans with mutations in RGS9 (Nishiguchi et al. 2004; Michaelides et al. 2010). In contrast, RGS9-2 is highly expressed in the striatum where it regulates opioidergic and dopaminergic responses (Gold et al. 1997). RGS proteins have been also implicated in regulating cancer progression. In many cases, the link is related to changes in expression. For instance, RGS2 and RGS4 mRNA are both down-regulated in ovarian cancer cell lines, in contrast to RGS6 mRNA which is upregulated, indicating different and specific functional roles for these proteins (for review, see Hurst and Hooks 2009).

\subsection{GPCR Dimerization}

Organization of GPCRs into dimeric clusters has been considered for more than 10 years and is now supported by numerous studies (Milligan 2009) and the crystal structure of two GPCRs (Palczewski et al. 2000; Wu et al. 2010). GPCR heterodimerization is a topic of great interest due to the potential importance of the functional consequences of such interactions on signal transduction pathways. Depending on the two protomers constituting the dimer (the dimer being the minimal functional oligomeric unit), the composition of the GAPCs can vary and generate signaling specificity (Fig. 12.1e). In addition, GPCR heterodimerization offers a plausible solution for the simultaneous binding of many interaction partners to the receptor and would increase the diversity of the activation response of such complexes.

Accumulating evidence in the literature indicates that heterodimerization may modify the $\mathrm{G}$ protein coupling profile. For instance, signaling of $\mu$ - and $\delta$-opioid receptor heterodimers is insensitive to pertussis toxin (PTX) treatment in contrast to the individually expressed receptors, suggesting a switch from PTX-sensitive to PTX-insensitive G protein coupling (George et al. 2000). Other studies on dopamine $D_{1}$ and $D_{2}$ receptor heterodimers demonstrated that the $G \alpha_{s}$-coupled $D_{1}$ and the $\mathrm{G} \alpha_{\mathrm{i}}$-coupled $\mathrm{D}_{2}$ receptors become $\mathrm{G} \alpha_{\mathrm{q} / 11}$-coupled in the corresponding heterodimer (Rashid et al. 2007). These examples illustrate how heterodimerization between two different GPCRs can determine signaling specificity.

Asymmetry between the two protomers of a GPCR dimer may also contribute to signaling specificity (for review, see (Maurice et al. 2011; Kamal et al. 2011). The recent development of a functional complementation assay allowed to explore the individual contribution of each protomer of class A GPCR dimers (Han et al. 2009). A trans-activation model was proposed in which the agonist-occupied protomer can trans-activate the second protomer that associates with the $\mathrm{G} \alpha$ subunit to modulate the signal transduction pathway. Another example in which asymmetry downstream of the $G$ protein determines signaling specificity was recently reported for the 
melatonin $\mathrm{MT}_{1} / \mathrm{MT}_{2}$ heterodimer and RGS20 (Maurice et al. 2010). In contrast to the $\mathrm{MT}_{2}$ receptor, which only couples to $\mathrm{G}_{\mathrm{i}}$ proteins, the $\mathrm{MT}_{1}$ receptor forms a constitutive ternary complex with both $\mathrm{G}_{\mathrm{i}}$ and RGS20. By using a ligand bindingdeficient $\mathrm{MT}_{1} *$ mutant and bioluminescence resonance energy transfer (BRET) studies with energy transfer probes at different sites of the MT/Gi/RGS20 complex, Maurice et al. showed that activation of the $\mathrm{MT}_{2}$ protomer, within the $\mathrm{MT}_{1}{ }^{*} / \mathrm{MT}_{2}$ heteromer, can cis-activate $\mathrm{G}_{\mathrm{i}}$, which then interacts functionally with RGS20 bound to the $\mathrm{MT}_{1}$ * protomer. This shows that receptors, such as $\mathrm{MT}_{2}$, that are insensitive to a specific GPCR-interacting protein (GIP) can become sensitive to the action of this GIP in the appropriate heterodimer complex.

Agonist binding to GPCRs and G protein activation are followed by the recruitment of $G$ protein-coupled receptor kinases (GRKs) that phosphorylate the receptor, and of arrestins triggering receptor endocytosis and arrestin-dependent signal transduction (Reiter and Lefkowitz 2006). The receptor/GRK stoichiometry remains unknown but several studies have reported that binding of only one GRK molecule to the receptor dimer might be sufficient for full receptor phosphorylation of both protomers by cross-phosphorylation. This phenomenon has been shown for rhodopsin for which recruitment of the rhodopsin kinase to an activated rhodopsin can cross-phosphorylate multiple nearby non-activated rhodopsin molecules (Shi et al. 2005) and for several other class A GPCR heteromers (Pfeiffer et al. 2002, 2003). In these studies, GRK cross-phosphorylation of the unligated GPCR within the heterodimer was accompanied by co-internalization of this unligated protomer together with the ligand-bound protomer of the dimer (Pfeiffer et al. 2002, 2003). Crossinternalization of receptors within GPCR heterodimers may have important functional consequences, as shown in the case of the $\mu / \delta$-opioid receptor heterodimer. Activation of the $\delta$-opioid receptor cross-internalizes $\mu$-opioid receptors, thereby severely limiting $\mu$-opioid receptor-associated morphine analgesia (He et al. 2011).

Taken together, these examples indicate how GPCR heterodimerization, by acting as scaffolds and by assembling distinct GAPCs, can generate signaling properties that differ from those observed in the corresponding homodimers thus illustrating the diversification of the functional properties of receptors by heterodimerization.

\subsection{Complex Formation with Membrane Proteins Other Than GPCRs}

GPCRs have not only been reported to cluster into homo- and heterodimeric complexes but also with other major transmembrane proteins as diverse as neurotransmitter transporters and ion channels, which are privileged pharmacological targets by themselves (Fig. 12.1f). A physical and functional interaction was reported between the $\gamma$-aminobutyric-acid $\mathrm{A}\left(\mathrm{GABA}_{\mathrm{A}}\right)$-ligand gated channel and the dopamine $\mathrm{D}_{5}$ receptor (Liu et al. 2000). Interestingly, this association was shown to enable mutually inhibitory effects resulting in $\mathrm{D}_{5}$ receptor-attenuated $\mathrm{GABA}_{\mathrm{A}}$ mediated inhibitory postsynaptic currents and $\mathrm{GABA}_{\mathrm{A}}$-stimulated reductions of $\mathrm{D}_{5}$ 


\section{Author's Proof}

12 Differential Assembly of GPCR Signaling Complexes Determines Signaling...

receptor cAMP accumulation. These findings are of primary importance since $\mathrm{GABA}_{\mathrm{A}}$ receptors mediate fast inhibitory synaptic transmission at the vast majority of inhibitory synapses in the brain, thereby playing a fundamental role in brain physiology and pathology.

The ionotropic $N$-methyl-D-aspartate (NMDA) receptor was also reported to physically interact with the $\mathrm{D}_{1}$ receptor (Lee et al. 2002) and more recently with the mGlu5a receptor (Perroy et al. 2008). NMDA receptors play an important role in the regulation of activity-dependent neuroplasticity and excitotoxicity and the interaction with $\mathrm{D}_{1}$ was reported to modulate NMDA receptor-mediated functions in hippocampal culture neurons (Lee et al. 2002). Interaction with mGlu5a allows reciprocal modulation of both receptors; the mGlu5a receptor decreases NMDA receptor currents and the NMDA receptor strongly reduces the ability of the mGlu5a receptor to release intracellular calcium (Perroy et al. 2008). These studies illustrate the richness in the functional interactions between a GPCR and other unrelated transmembrane receptors, leading to a much higher degree of effector specificity and subcellular signaling pathways.

The nociceptin (ORL1) receptor has been shown to physically and specifically interact with another type of ion channel, the voltage-gated $\mathrm{N}$-type $\mathrm{Ca}_{\mathrm{v}} 2.2$ calcium channel (Beedle et al. 2004). Calcium influx through $\mathrm{N}$-type calcium channels in dorsal root ganglion (DRG) neurons is an essential step in the transmission of nociceptive signals at the spinal level. Specific interaction between ORL1 and $\mathrm{Ca}_{\mathrm{v}} 2.2$ has been shown to result in an agonist-independent, receptor concentration-dependent inhibition of the channel in vitro and in DRG neurons (Beedle et al. 2004). These findings raised the possibility that the activity of N-type calcium channels, and consequently transmission of pain signals, may be regulated by difference in GPCR (ORL1) receptor density. Further characterization of the ORL1/Ca 2.2 interaction showed that prolonged exposure of ORL1 to its cognate agonist nociceptin triggers co-internalization of ORL1 and the ion channel thus down-regulating calcium entry in DRG neurons (Altier et al. 2006).

Preferential interactions have also been reported between GPCRs and neurotransmitter transporters. The dopamine $\mathrm{D}_{2}$ and orphan GPR37 receptor have been shown to interact with the dopamine transporter (DAT), one of the key presynaptic components involved in regulating dopaminergic tone. The physical coupling between DAT and $\mathrm{D}_{2}$ facilitates the recruitment of intracellular DAT to the plasma membrane, thus enhancing dopamine reuptake in primary cultures of rat midbrain neurons. Disruption of the $\mathrm{D}_{2} / \mathrm{DAT}$ interaction in mice decreases synaptosomal dopamine uptake and increases locomotor activity (Lee et al. 2007). Interestingly, opposite effects have been reported following interaction of DAT with GPR37 (Marazziti et al. 2007). Gpr37-null mutant mice show enhanced DAT-mediated dopamine uptake in striatal membrane samples, with a significant increase in the number of membrane DAT molecules. Taken together, these two studies demonstrate how, according to the nature of the GPCR engaged in a complex with a neurotransmitter transporter, opposite functional effects can be observed.

Formation of stable GPCR-effector complexes within the plasma membrane is also exemplified by GPCRs and $G$ protein-gated inwardly-rectifying $\mathrm{K}^{+}$(GIRK) 


\section{Author's Proof}

channels, particularly of family 3 (Kir3). Kir3 channels represent a family of ion channels that mediate the postsynaptic inhibitory effect of many neurotransmitters and drugs of abuse. In 2002, a first study reported the formation of stable complexes of Kir3 with $D_{2}$-like, $D_{4}$ and $\beta_{2}$ adrenergic receptors using co-immunoprecipitation and BRET experiments (Lavine et al. 2002), Further studies reported formation of such complexes with other GPCRs such as $\mathrm{GABA}_{\mathrm{B}}$ receptors (David et al. 2006; Ciruela et al. 2010; Fowler et al. 2007), and muscarinic $\mathrm{M}_{2}$, serotonin $1_{A}$, adenosine $\mathrm{A}_{1}$, and LPA 1 receptors (Jaen and Doupnik 2006).

Overall, these different studies suggest that assemblies containing these components may represent a common organizational premise needed to determine specificity and efficacy of signal transduction and may be critical to assure the speed of signaling.

\subsection{Physiological Changes, Illustrated by Circadian Rhythmicity}

The cellular state is constantly changing depending on the cell cycle and the developmental stage of the organism. An interesting regular modification of biological systems is imposed by the biological clock that generates circadian rhythmicity at the cellular level. It is estimated that at least $10 \%$ of all genes are cycling in a circadian manner, which has obviously important functional consequences on cellular homeostasis (Lowrey and Takahashi 2004). Two recent examples illustrate the direct impact of circadian rhythmicity on GPCR function (Fig. 12.1h).

In mammals, the hypothalamic suprachiasmatic nucleus $(\mathrm{SCN})$ is the central pacemaker, generating an endogenous and self-sustained circadian activity and coordinating rhythms of numerous peripheral tissues (Sujino et al. 2003). Circadian rhythmicity is generated at the cellular level but how the phase and period of circadian oscillation of different SCN neurons is maintained remains largely unknown. Oscillation in intracellular cyclic adenosine monophosphate (cAMP) levels is known to be an important component of circadian rhythmicity. The cAMP system can be manipulated by several means. cAMP production is controlled by stimulating $G_{s}$ or $G_{i}$ protein-coupled receptors that activate or inhibit adenylyl cyclases, respectively. Degradation of cAMP occurs through phosphodiesterases. In addition, RGS proteins such as RGS16 may inhibit the function of $\mathrm{G}_{\mathrm{i}}$ proteins by accelerating their GTP-GDP exchange rate. Interestingly, RGS16 is expressed in a circadian manner in the dorsomedial part of the SCN with peak levels during dawn modulating cAMP signaling in a highly regulated spatiotemporal manner (Doi et al. 2011). Ablation of the Rgs 16 gene eliminates the circadian cAMP production and, as a result, lengthened the circadian period of the locomotor activity rhythm thus demonstrating the importance of defined circadian activation patterns for behavioral outputs. This is further underlined by the fact that cAMP levels in Rgs 16 knockout mice remained constant at an elevated level demonstrating that not elevated cAMP levels per se but rather their rhythmicity are important. Taken together, rhythmic 


\section{Author's Proof}

changes in the expression of an important component of GPCR signaling, RGS16, 282 may define signaling specificity in a temporal manner.

Another example illustrating the impact of the circadian rhythm on GPCR signaling has been shown in a peripheral organ, the liver (Zhang et al. 2010). In hepatic cells, intracellular cAMP levels appear to be regulated by a core component of the circadian rhythm generating cellular machinery, cryptochrome proteins (Cry). Circadian control of gene expression is achieved by two transcriptional activators, Clock and Bmal1, which stimulate Cry1, Cry2 and Period repressors that feedback on Clock-Bmal1 activity (Reppert and Weaver 2002). Recent evidence indicates that Cry may have additional, extra-nuclear, functions in hepatocytes (Zhang et al. 2010). Cry protein expression is rhythmic with peak levels during the night-day transition. By interacting with $\mathrm{G}_{\mathrm{s}}$ proteins, Cry diminishes intracellular cAMP levels in a circadian manner due to its circadian expression pattern. This may be of physiological relevance as the liver clock regulates the gluconeogenic genetic program through Cry-mediated inhibition of CREB activity during fasting. Furthermore, hepatic overexpression of Cry1 lowered blood glucose concentrations and improved insulin sensitivity in insulin-resistant $\mathrm{db} / \mathrm{db}$ mice suggesting that enhancing Cry activity might be beneficial in type 2 diabetes treatment. Taken together, circadian expression of proteins involved in the regulation of GPCR signaling provides a powerful means to control GPCR signaling specificity.

\subsection{Localization of GPCRs at Different Subcellular Compartments}

GPCR signaling specificity can be modulated depending on receptor localization at different subcellular compartments (Fig. 12.1g). Targeting of receptors to these compartments determines receptor function due to the specific physicochemical properties of each compartment (membrane rigidity and lipid composition) and the enrichment of GAPCs and signaling pathway components in these compartments. Microdomains (lipid rafts and caveolae) are specialized compartments of the plasma membrane that are highly structured zones of low fluidity due to their enrichment in cholesterol and sphingolipids. The structural integrity of caveolae is further maintained by a coat composed of caveolin protein at the cytoplasmic side. Microdomains have been suggested to constitute a scaffolding zone of GPCR signaling cascades that also modify GPCR trafficking and favor crosstalk with other signaling pathways. The precise mechanism of GPCR targeting into these microdomains remains unclear, in particular whether some GPCRs show higher intrinsic affinity for microdomains than others or whether microdomain-enriched GAPCs target GPCR to these domains (Insel et al. 2005). Furthermore, the impact of microdomains on GPCR localization and signaling specificity may vary depending on the tissue, as some cells, such as adipocytes, are richer in microdomains than others.

An obvious role of caveolae in determining the functional outcome of GPCR signaling is provided by caveolae-localized PAR1 receptors that phosphorylate 


\section{Author's Proof}

caveolin-1 in a Src-dependent manner. Phosphocaveolin-1 then binds to the SH2 domain of the C-terminal Src kinase (Csk) resulting in a rapid decrease in Src kinase activity. Thus, PAR1-induced Src activation is down-regulated by recruiting Csk specifically in caveolin-1 containing microdomains (Lu et al. 2006).

GnRH receptors have been shown to constitutively localize within microdomains as part of a preformed signaling complex composed of caveolin-1, c-Src, protein kinase C, Ras, MAPK kinase 1/2, ERK1/2, tubulin, FAK, paxillin, vinculin, and kinase suppressor of Ras-1 (Dobkin-Bekman et al. 2009). Stimulation by GnRH induces molecular rearrangement of the complex, the rapid dissociation of some components and the phosphorylation of FAK and paxillin by EKR1/2. Whereas activation of ERK1/2 typically induces their nuclear translocation and phosphorylation of transcription factors, scaffolding into microdomain-associated multiprotein signaling complexes, as described here, helps to maintain the activated ERK1/2 pool within the cytoplasm and to phosphorylate FAK and paxillin at focal adhesions.

Primary cilia are appendages present at the cell surface on most mammalian cells involved in signal sensing and transmission (Goetz and Anderson 2010). Some GPCRs, including somatostatin receptor 3, serotonin receptor 6, smoothened, dopamine $\mathrm{D}_{1}$ receptor and melanin-concentrating hormone receptor 1 localize to cilia. The importance of the localization and signaling of GPCRs in primary cilia is suggested by altered signaling caused by the absence of cilia formation (Berbari et al. 2009). Some molecular determinants directing localization of GPCRs to cilia have been identified in the third intracellular loop, which most likely binds to cytoskeleton proteins involved in the transport into and out of cilia (Berbari et al. 2008). The functions of cilia are defined by the signaling proteins localized to the ciliary membrane such as adenylyl cyclases, heterotrimeric $G$ proteins and $\beta$-arrestins. What makes primary cilia so special compared to other cell surface-exposed membrane regions, remains still an open question and warrants further investigation.

Many GPCRs contain a PSD-95/Disc large/Zonula occludens 1 (PDZ) ligand sequence composed of three amino acids at their carboxyl-terminal extremity (Heydorn et al. 2004). These PDZ ligands are recognized by PDZ domains, which are present in almost 200 proteins. PDZ domains are scaffolding domains per excellence that are involved in GPCR trafficking and subcellular localization. The postsynaptic density protein 95 (PSD95) contains three PDZ domains and interacts with the serotonin $5-\mathrm{HT}_{2 \mathrm{C}}$ receptor and other GPCRs in post-synaptic membranes (Becamel et al. 2002). PSD95 is also part of large molecular networks such as the PSD95/GKAP/Shank/Homer3 complex that physically and functionally connects NMDA receptors (PSD95 binding partner) to metabotropic glutamate 5 receptors (mGluR5) (Homayoun and Moghaddam 2010). Homer three proteins assemble into tetramers bridging GKAP and mGluR5. Interestingly, this complex can be disrupted by the monomeric immediate early gene Homerla that blocks the interaction between GKAP and mGluR5 by competing with Homer3. This indicates a dynamic regulation of the presence of mGluR5 in the complex and possibly its localization to post-synaptic membranes (Bertaso et al. 2010).

Signaling of GPCRs has been reported not only at the plasma membrane or specialized plasma membrane sub-compartments such as microdomains, primary 


\section{Author's Proof}

12 Differential Assembly of GPCR Signaling Complexes Determines Signaling...

cilia and synapses, but also in intracellular membranes such as endosomes and nuclear membranes (Boivin et al. 2008; Calebiro et al. 2010). GAPCs appear to play an important role under these circumstances as current observations are compatible with the joint translocation of both receptors and their GAPCs from the cell surface to intracellular compartments to prolong their signaling capacity. It remains however unclear why these complexes remain stable during receptor endocytosis and which component is responsible for the targeting of the complex to specific intracellular sites. Although it is tempting to speculate that specific GAPCs participate in this new paradigm of signaling specificity, experimental proof for this hypothesis is still lacking.

\subsection{Targeting GPCR-GIP Interaction In Vivo: A Promising Approach for Specific Therapeutic Intervention?}

An important issue concerns the pathophysiological relevance of such differential assembly of GAPCs. Indeed, the potential of targeting GPCR-GIP interactions as a novel approach for therapeutic intervention is of particular interest and specific disruption of a GPCR/GIP interaction in a given tissue without affecting the interaction of this same GPCR with other GIPs in another tissue represents an attractive strategy for drug discovery. Emerging evidence that illustrate this concept came from studies based on the use of cell-penetrating HIV TAT-conjugated peptides that clearly showed the potential of peptides in disrupting a specific GPCR/GIP interaction.

A first example was proposed by the study of Ji et al. (2006) reporting that intravenous injection in rats of a TAT-conjugated peptide encompassing the PTENbinding motif located within the i3 loop of 5- $\mathrm{HT}_{2 \mathrm{C}}$ receptor suppresses the firing rate of ventral tegmental area (VTA) dopaminergic neurons induced by d9-tetrahydrocannabinol (THC), thereby reproducing the effect of $5-\mathrm{HT}_{2 \mathrm{C}}$ receptor agonists. As $5-\mathrm{HT}_{2 \mathrm{C}}$ receptor agonists, this TAT-peptide also inhibits the rewarding effects of THC (and nicotine) mediated by VTA dopaminergic neurons. However, it does not reproduce the side effects (anxiogenic effects, penile erection, hypophagia, and motor functional suppression) observed following administration of 5- $\mathrm{HT}_{2 \mathrm{C}}$ agonists (Ji et al. 2006).

Disruption of the mGluR7a/PICK1 interaction by intravenous injection of a TATconjugated peptide was able to trigger absence epilepsy-like seizures in mice and rats, providing evidence that a single PDZ protein/GPCR interaction can result in a specific neurological disorder (Bertaso et al. 2008). More recently, disruption of the interaction between 5- $\mathrm{HT}_{2 \mathrm{~A}}$ and $\mathrm{PDZ}$ proteins in diabetic neuropathic rats by a TATconjugated peptide encompassing the nine $\mathrm{C}$-terminal residues of the $5-\mathrm{HT}_{2 \mathrm{~A}}$ receptor was shown to induce an antihyperalgesic effect and to strongly enhance antihyperalgesia induced by the selective serotonin reuptake inhibitor (SSRI) fluoxetine. This study thus suggests that $5-\mathrm{HT}_{2 \mathrm{~A}}$ receptor/PDZ protein interactions might contribute to the resistance to SSRI-induced analgesia in painful diabetic neuropathy and that disruption of these interactions might be a valuable strategy to 


\section{Author's Proof}

409

410

411

412

413

414

415

416

417

418

419

420

design novel treatments for neuropathic pain and to increase the effectiveness of SSRIs (Pichon et al. 2010).

The importance of $D_{1} / D_{2}$ heterodimers in human disease was suggested in a recent study showing that physical interaction between dopamine $\mathrm{D}_{1}$ and $\mathrm{D}_{2}$ receptors is markedly increased in postmortem brains of patients suffering from major depression. Administration of an interfering peptide consisting of a sequence located in the third intracellular loop of $\mathrm{D}_{2}$ that disrupts the $\mathrm{D}_{1}-\mathrm{D}_{2}$ receptor complex reduced immobility in the forced swim test without affecting locomotor activity, and decreased escape failures in learned helplessness tests in rats (Pei et al. 2010). This study thus provided evidence for potential implication of GPCR heterodimers and associated signaling specificity in human diseases.

\subsection{Conclusions}

Evolution has selected several ways to achieve signaling specificity, by generating receptor isoforms, receptor polymorphisms, differential localization and targeting of receptors and pre-assembly of receptors and GAPCs into defined and distinct signaling modules. The latter holds the potential to explain many of the observed signaling specificity. However, we are only beginning to define the precise composition and impact of these modules on receptor signaling. Given the dynamic nature of these modules, a precise analysis has to be performed for each receptor in a specific cellular context and under defined physiological and pathological conditions.

Acknowledgements We thank Jean-Luc Guillaume (Institut Cochin, Paris) for critical reading of the manuscript. This work was supported by grants from the Fondation pour la Recherche Médicale ("Equipe FRM", to RJ), Institut National de la Santé et de la Recherche Médicale (INSERM), Centre National de la Recherche Scientifique (CNRS), Servier and a research fellowship from the Ile-de-France region $(\mathrm{ABC})$.

\section{References}

Adan RA, Kas MJ (2003) Inverse agonism gains weight. Trends Pharmacol Sci 24(6):315-321

Altier C, Khosravani H, Evans RM, Hameed S, Peloquin JB, Vartian BA, Chen L, Beedle AM, Ferguson SS, Mezghrani A, Dubel SJ, Bourinet E, McRory JE, Zamponi GW (2006) ORL1 receptor-mediated internalization of N-type calcium channels. Nat Neurosci 9(1):31-40. doi:10.1038/nn1605, pii:nn1605

Becamel C, Alonso G, Geleotti N, Demey E, Jouin P, Ullmer C, Dumuis A, Bockaert J, Marin P (2002) Synaptic multiprotein complexes associated with 5-HT2C receptors: a proteomic approach. EMBO J 21(10):2332-2342

Beedle AM, McRory JE, Poirot O, Doering CJ, Altier C, Barrere C, Hamid J, Nargeot J, Bourinet E, Zamponi GW (2004) Agonist-independent modulation of N-type calcium channels by ORL1 receptors. Nat Neurosci 7(2):118-125 
Berbari NF, Johnson AD, Lewis JS, Askwith CC, Mykytyn K (2008) Identification of ciliary localization sequences within the third intracellular loop of $\mathrm{G}$ protein-coupled receptors. Mol Biol Cell 19(4):1540-1547. doi:10.1091/mbc.E07-09-0942, pii:E07-09-0942

Berbari NF, O'Connor AK, Haycraft CJ, Yoder BK (2009) The primary cilium as a complex signaling center. Curr Biol 19(13):R526-R535. doi:10.1016/j.cub.2009.05.025, pii:S0960-9822 (09)01126-9

Bertaso F, Zhang C, Scheschonka A, de Bock F, Fontanaud P, Marin P, Huganir RL, Betz H, Bockaert J, Fagni L, Lerner-Natoli M (2008) PICK1 uncoupling from mGluR7a causes absence-like seizures. Nat Neurosci 11(8):940-948. doi:10.1038/nn.2142, pii:nn.2142

Bertaso F, Roussignol G, Worley P, Bockaert J, Fagni L, Ango F (2010) Homer1a-dependent crosstalk between NMDA and metabotropic glutamate receptors in mouse neurons. PLoS One 5(3):e9755. doi:10.1371/journal.pone.0009755

Boivin B, Vaniotis G, Allen BG, Hebert TE (2008) G protein-coupled receptors in and on the cell nucleus: a new signaling paradigm? J Recept Signal Transduct Res 28(1-2):15-28. doi:10.1080/10799890801941889, pii:792548935

Calebiro D, Nikolaev VO, Persani L, Lohse MJ (2010) Signaling by internalized G-protein-coupled receptors. Trends Pharmacol Sci 31(5):221-228. doi:10.1016/j.tips.2010.02.002, pii:S01656147(10)00014-3

Ciruela F, Fernandez-Duenas V, Sahlholm K, Fernandez-Alacid L, Nicolau JC, Watanabe M, Lujan R (2010) Evidence for oligomerization between GABAB receptors and GIRK channels containing the GIRK1 and GIRK3 subunits. Eur J Neurosci 32(8):1265-1277. doi:10.1111/ j.1460-9568.2010.07356.x

Cowan CW, Fariss RN, Sokal I, Palczewski K, Wensel TG (1998) High expression levels in cones of RGS9, the predominant GTPase accelerating protein of rods. Proc Natl Acad Sci USA 95(9):5351-5356

David M, Richer M, Mamarbachi AM, Villeneuve LR, Dupre DJ, Hebert TE (2006) Interactions between GABA-B1 receptors and Kir 3 inwardly rectifying potassium channels. Cell Signal 18(12):2172-2181. doi:10.1016/j.cellsig.2006.05.014, pii:S0898-6568(06)00102-1

Dobkin-Bekman M, Naidich M, Rahamim L, Przedecki F, Almog T, Lim S, Melamed P, Liu P, Wohland T, Yao Z, Seger R, Naor Z (2009) A preformed signaling complex mediates GnRHactivated ERK phosphorylation of paxillin and FAK at focal adhesions in L beta T2 gonadotrope cells. Mol Endocrinol 23(11):1850-1864. doi:10.1210/me.2008-0260, pii:me. 2008-0260

Doi M, Ishida A, Miyake A, Sato M, Komatsu R, Yamazaki F, Kimura I, Tsuchiya S, Kori H, Seo K, Yamaguchi Y, Matsuo M, Fustin JM, Tanaka R, Santo Y, Yamada H, Takahashi Y, Araki M, Nakao K, Aizawa S, Kobayashi M, Obrietan K, Tsujimoto G, Okamura H (2011) Circadian regulation of intracellular G-protein signalling mediates intercellular synchrony and rhythmicity in the suprachiasmatic nucleus. Nat Commun 2:327. doi:10.1038/ncomms1316, pii:ncomms1316

Ferrandon S, Feinstein TN, Castro M, Wang B, Bouley R, Potts JT, Gardella TJ, Vilardaga JP (2009) Sustained cyclic AMP production by parathyroid hormone receptor endocytosis. Nat Chem Biol 5(10):734-742. doi:10.1038/nchembio.206, pii:nchembio.206

Fowler CE, Aryal P, Suen KF, Slesinger PA (2007) Evidence for association of GABA(B) receptors with Kir3 channels and regulators of G protein signalling (RGS4) proteins. J Physiol 580(Pt 1):51-65. doi:10.1113/jphysiol.2006.123216, pii:jphysiol.2006.123216

Fredriksson R, Schioth HB (2005) The repertoire of G-protein-coupled receptors in fully sequenced genomes. Mol Pharmacol 67(5):1414-1425

George SR, Fan T, Xie ZD, Tse R, Tam V, Varghese G, O'Dowd BF (2000) Oligomerization of mu- and delta-opioid receptors - generation of novel functional properties. J Biol Chem 275(34):26128-26135

Goetz SC, Anderson KV (2010) The primary cilium: a signalling centre during vertebrate development. Nat Rev Genet 11(5):331-344. doi:10.1038/nrg2774, pii:nrg2774

Gold SJ, Ni YG, Dohlman HG, Nestler EJ (1997) Regulators of G-protein signaling (RGS) proteins: region-specific expression of nine subtypes in rat brain. J Neurosci 17(20):8024-8037 
Han Y, Moreira IS, Urizar E, Weinstein H, Javitch JA (2009) Allosteric communication between protomers of dopamine class A GPCR dimers modulates activation. Nat Chem Biol 5(9):688-695

He W, Cowan CW, Wensel TG (1998) RGS9, a GTPase accelerator for phototransduction. Neuron 20(1):95-102, pii:S0896-6273(00)80437-7

He SQ, Zhang ZN, Guan JS, Liu HR, Zhao B, Wang HB, Li Q, Yang H, Luo J, Li ZY, Wang Q, Lu YJ, Bao L, Zhang X (2011) Facilitation of mu-opioid receptor activity by preventing delta-opioid receptor-mediated codegradation. Neuron 69(1):120-131.doi:10.1016/j.neuron.2010.12.001, pii:S0896-6273(10)00986-4

Heydorn A, Sondergaard BP, Ersboll B, Holst B, Nielsen FC, Haft CR, Whistler J, Schwartz TW (2004) A library of 7TM receptor C-terminal tails. Interactions with the proposed post-endocytic sorting proteins ERM-binding phosphoprotein 50 (EBP50), N-ethylmaleimide-sensitive factor (NSF), sorting nexin 1 (SNX1), and G protein-coupled receptor-associated sorting protein (GASP). J Biol Chem 279(52):54291-54303

Homayoun H, Moghaddam B (2010) Group 5 metabotropic glutamate receptors: role in modulating cortical activity and relevance to cognition. Eur J Pharmacol 639(1-3):33-39. doi:10.1016/j. ejphar.2009.12.042, pii:S0014-2999(10)00254-2

Hurst JH, Hooks SB (2009) Regulator of G-protein signaling (RGS) proteins in cancer biology. Biochem Pharmacol 78(10):1289-1297. doi:10.1016/j.bcp.2009.06.028, pii:S0006-2952(09) 00497-3

Insel PA, Head BP, Ostrom RS, Patel HH, Swaney JS, Tang CM, Roth DM (2005) Caveolae and lipid rafts: $G$ protein-coupled receptor signaling microdomains in cardiac myocytes. Ann N Y Acad Sci 1047:166-172. doi:10.1196/annals.1341.015, pii:1047/1/166

Jaen C, Doupnik CA (2006) RGS3 and RGS4 differentially associate with G protein-coupled receptor-Kir3 channel signaling complexes revealing two modes of RGS modulation. Precoupling and collision coupling. J Biol Chem 281(45):34549-34560. doi:10.1074/jbc. M603177200, pii:M603177200

Ji SP, Zhang Y, Van Cleemput J, Jiang W, Liao M, Li L, Wan Q, Backstrom JR, Zhang X (2006) Disruption of PTEN coupling with 5-HT2C receptors suppresses behavioral responses induced by drugs of abuse. Nat Med 12(3):324-329. doi:10.1038/nm1349, pii:nm1349

Kamal M, Maurice P, Jockers R (2011) Expanding the concept of G protein-coupled receptor (GPCR) dimer asymmetry towards GPCR-interacting proteins. Pharmaceuticals 4:273-284

Lavine N, Ethier N, Oak JN, Pei L, Liu F, Trieu P, Rebois RV, Bouvier M, Hebert TE, Van Tol HH (2002) G protein-coupled receptors form stable complexes with inwardly rectifying potassium channels and adenylyl cyclase. J Biol Chem 277(48):46010-46019. doi:10.1074/jbc. M205035200, pii:M205035200

Lee FJ, Xue S, Pei L, Vukusic B, Chery N, Wang Y, Wang YT, Niznik HB, Yu XM, Liu F (2002) Dual regulation of NMDA receptor functions by direct protein-protein interactions with the dopamine D1 receptor. Cell 111(2):219-230, pii:S0092867402009625

Lee FJ, Pei L, Moszczynska A, Vukusic B, Fletcher PJ, Liu F (2007) Dopamine transporter cell surface localization facilitated by a direct interaction with the dopamine D2 receptor. EMBO J 26(8):2127-2136. doi:10.1038/sj.emboj.7601656, pii:7601656

Liu F, Wan Q, Pristupa ZB, Yu XM, Wang YT, Niznik HB (2000) Direct protein-protein coupling enables cross-talk between dopamine D5 and gamma-aminobutyric acid A receptors. Nature 403(6767):274-280. doi:10.1038/35002014

Lowrey PL, Takahashi JS (2004) Mammalian circadian biology: elucidating genome-wide levels of temporal organization. Annu Rev Genomics Hum Genet 5:407-441. doi:10.1146/annurev. genom.5.061903.175925

Lu TL, Kuo FT, Lu TJ, Hsu CY, Fu HW (2006) Negative regulation of protease-activated receptor 1-induced Src kinase activity by the association of phosphocaveolin-1 with Csk. Cell Signal 18(11):1977-1987. doi:10.1016/j.cellsig.2006.03.002, pii:S0898-6568(06)00068-4

Mancuso JJ, Qian Y, Long C, Wu GY, Wensel TG (2010) Distribution of RGS9-2 in neurons of the mouse striatum. J Neurochem 112(3):651-661. doi:10.1111/j.1471-4159.2009.06488.x, pii:JNC6488 


\section{Author's Proof}

12 Differential Assembly of GPCR Signaling Complexes Determines Signaling...

Marazziti D, Mandillo S, Di Pietro C, Golini E, Matteoni R, Tocchini-Valentini GP (2007) GPR37 associates with the dopamine transporter to modulate dopamine uptake and behavioral responses to dopaminergic drugs. Proc Natl Acad Sci USA 104(23):9846-9851

Maurice P, Daulat AM, Turecek R, Ivankova-Susankova K, Zamponi F, Kamal M, Clement N, Guillaume JL, Bettler B, Gales C, Delagrange P, Jockers R (2010) Molecular organization and dynamics of the melatonin MT receptor/RGS20/G(i) protein complex reveal asymmetry of receptor dimers for RGS and G(i) coupling. EMBO J 29(21):3646-3659. doi:10.1038/ emboj.2010.236, pii:emboj2010236

Maurice P, Kamal M, Jockers R (2011) Asymmetry of GPCR oligomers supports their functional relevance. Trends Pharmacol Sci 32(9):514-520. doi:10.1016/j.tips.2011.05.006, pii:S01656147(11)00095-2

[AU4] Michaelides M, Li Z, Rana NA, Richardson EC, Hykin PG, Moore AT, Holder GE, Webster AR (2010) Novel mutations and electrophysiologic findings in RGS9- and R9AP-associated retinal dysfunction (Bradyopsia). Ophthalmology 117(1):120-127 e121. doi:10.1016/j.ophtha.2009.06.011, pii:S0161-6420(09)00613-7

Milligan G (2009) G protein-coupled receptor hetero-dimerization: contribution to pharmacology and function. Br J Pharmacol 158(1):5-14

Nishiguchi KM, Sandberg MA, Kooijman AC, Martemyanov KA, Pott JW, Hagstrom SA, Arshavsky VY, Berson EL, Dryja TP (2004) Defects in RGS9 or its anchor protein R9AP in patients with slow photoreceptor deactivation. Nature 427(6969):75-78. doi:10.1038/ nature 02170

Palczewski K, Kumasaka T, Hori T, Behnke CA, Motoshima H, Fox BA, LeTrong I, Teller DC, Okada T, Stenkamp RE, Yamamoto M, Miyano M (2000) Crystal structure of rhodopsin: a G protein-coupled receptor. Science 289(5480):739-745

Pei L, Li S, Wang M, Diwan M, Anisman H, Fletcher PJ, Nobrega JN, Liu F (2010) Uncoupling the dopamine D1-D2 receptor complex exerts antidepressant-like effects. Nat Med 16(12):13931395. doi:10.1038/nm.2263, pii:nm.2263

Perroy J, Raynaud F, Homburger V, Rousset MC, Telley L, Bockaert J, Fagni L (2008) Direct interaction enables cross-talk between ionotropic and group I metabotropic glutamate receptors. J Biol Chem 283(11):6799-6805. doi:10.1074/jbc.M705661200, pii:M705661200

Pfeiffer M, Koch T, Schroder H, Laugsch M, Hollt V, Schulz S (2002) Heterodimerization of somatostatin and opioid receptors cross-modulates phosphorylation, internalization, and desensitization. J Biol Chem 277(22):19762-19772

Pfeiffer M, Kirscht S, Stumm R, Koch T, Wu D, Laugsch M, Schroder H, Hollt V, Schulz S (2003) Heterodimerization of substance $\mathrm{P}$ and mu-opioid receptors regulates receptor trafficking and resensitization. J Biol Chem 278(51):51630-51637. doi:10.1074/jbc.M307095200, pii:M307095200

Pichon X, Wattiez AS, Becamel C, Ehrlich I, Bockaert J, Eschalier A, Marin P, Courteix C (2010) Disrupting 5-HT(2A) receptor/PDZ protein interactions reduces hyperalgesia and enhances SSRI efficacy in neuropathic pain. Mol Ther 18(8):1462-1470. doi:10.1038/mt.2010.101, pii:mt2010101

Rashid AJ, So CH, Kong MM, Furtak T, El-Ghundi M, Cheng R, O’Dowd BF, George SR (2007) D1-D2 dopamine receptor heterooligomers with unique pharmacology are coupled to rapid activation of Gq/11 in the striatum. Proc Natl Acad Sci USA 104(2):654-659

Reiner S, Ambrosio M, Hoffmann C, Lohse MJ (2010) Differential signaling of the endogenous agonists at the beta2-adrenergic receptor. J Biol Chem 285(46):36188-36198. doi:10.1074/jbc. M110.175604, pii:M110.175604

Reiter E, Lefkowitz RJ (2006) GRKs and beta-arrestins: roles in receptor silencing, trafficking and signaling. Trends Endocrinol Metab 17(4):159-165

Reppert SM, Weaver DR (2002) Coordination of circadian timing in mammals. Nature 418(6901):935-941

Shen HC, Ding FX, Raghavan S, Deng Q, Luell S, Forrest MJ, Carballo-Jane E, Wilsie LC, Krsmanovic ML, Taggart AK, Wu KK, Wu TJ, Cheng K, Ren N, Cai TQ, Chen Q, Wang J, 


\section{Author's Proof}

Wolff MS, Tong X, Holt TG, Waters MG, Hammond ML, Tata JR, Colletti SL (2010) Discovery of a biaryl cyclohexene carboxylic acid (MK-6892): a potent and selective high affinity niacin receptor full agonist with reduced flushing profiles in animals as a preclinical candidate. J Med Chem 53(6):2666-2670. doi:10.1021/jm100022r

Shi GW, Chen J, Concepcion F, Motamedchaboki K, Marjoram P, Langen R (2005) Light causes phosphorylation of nonactivated visual pigments in intact mouse rod photoreceptor cells. J Biol Chem 280(50):41184-41191. doi:10.1074/jbc.M506935200, pii:M506935200

Sjogren B (2011) Regulator of G protein signaling proteins as drug targets: current state and future possibilities. Adv Pharmacol 62:315-347. doi:10.1016/B978-0-12-385952-5.00002-6, pii:B9780-12-385952-5.00002-6

Sujino M, Masumoto KH, Yamaguchi S, van der Horst GT, Okamura H, Inouye ST (2003) Suprachiasmatic nucleus grafts restore circadian behavioral rhythms of genetically arrhythmic mice. Curr Biol 13(8):664-668, pii:S0960982203002227

Vassilatis DK, Hohmann JG, Zeng H, Li F, Ranchalis JE, Mortrud MT, Brown A, Rodriguez SS, Weller JR, Wright AC, Bergmann JE, Gaitanaris GA (2003) The G protein-coupled receptor repertoires of human and mouse. Proc Natl Acad Sci USA 100(8):4903-4908

Walters RW, Shukla AK, Kovacs JJ, Violin JD, DeWire SM, Lam CM, Chen JR, Muehlbauer MJ, Whalen EJ, Lefkowitz RJ (2009) Beta-Arrestin1 mediates nicotinic acid-induced flushing, but not its antilipolytic effect, in mice. J Clin Invest 119(5):1312-1321. doi:10.1172/JCI36806, pii:36806

Wu B, Chien EY, Mol CD, Fenalti G, Liu W, Katritch V, Abagyan R, Brooun A, Wells P, Bi FC, Hamel DJ, Kuhn P, Handel TM, Cherezov V, Stevens RC (2010) Structures of the CXCR4 chemokine GPCR with small-molecule and cyclic peptide antagonists. Science 330(6007):10661071. doi:10.1126/science.1194396, pii:science.1194396

Zhang EE, Liu Y, Dentin R, Pongsawakul PY, Liu AC, Hirota T, Nusinow DA, Sun X, Landais S, Kodama Y, Brenner DA, Montminy M, Kay SA (2010) Cryptochrome mediates circadian regulation of cAMP signaling and hepatic gluconeogenesis. Nat Med 16(10):1152-1156. doi:10.1038/nm.2214, pii:nm.2214 


\section{Author's Proof}

Chapter No.: 12

\section{Author Queries}

\begin{tabular}{|l|l|l|}
\hline Queries & Details Required & Author's Response \\
\hline AU1 & Please provide organisation division for all the authors. & \\
\hline AU2 & Please confirm the affiliation details. & \\
\hline AU3 & $\begin{array}{l}\text { Please provide closing parenthesis in the sentence begins with } \\
\text { "for review, see".... }\end{array}$ & \\
\hline AU4 & $\begin{array}{l}\text { Please confirm the page range for the Reference Michaelides } \\
\text { et al. (2010). }\end{array}$ & \\
\hline
\end{tabular}

